\title{
Colletotrichum siamense, a Mycovirus-Carrying Endophyte, as a Biological Control Strategy for Anthracnose in Guarana Plants
}

Luana Lopes Casas ${ }^{1 *}$

https://orcid.org/0000-0003-0917-1941

\section{Lucas Nascimento de Almeida ${ }^{2}$}

https://orcid.org/0000-0001-9846-111X

José Odair Pereira ${ }^{2}$

https://orcid.org/0000-0002-0441-381X

\section{Pedro de Queiroz Costa Neto ${ }^{2}$}

https://orcid.org/0000-0002-1907-7492

João Lúcio de Azevedo ${ }^{3}$

https://orcid.org/0000-0003-0503-3525

${ }^{1}$ Amazonas State University, Postgraduate Programme in Biodiversity and Biotechnology - Bionorte, Higher School of Health Sciences, Manaus, Amazonas, Brazil; ${ }^{2}$ Federal University of Amazonas, School of Agricultural Sciences, Manaus, Amazonas, Brazil; 3University of São Paulo, Luiz de Queiroz School of Agriculture, Piracicaba, São Paulo, Brazil.

Editor-in-Chief: Paulo Vitor Farago

Associate Editor: Jane Manfron Budel

Received: 2020.08.19; Accepted: 2021.02.16.

*Correspondence: luanacasas05@gmail.com; Tel.: +55 98135-9367 (L.L.C).

\section{HIGHLIGHTS}

- Colletotrichum siamense and $C$. fructicola were identified in guarana plants.

- C. siamense, a mycovirus-carrying endophyte, protects the plant against a phytopathogenic fungus.

- C. siamense with the mycovirus stimulates the growth of Paullinia cupana plants.

Abstract: Guarana, the fruit of Paullinia cupana, is known for its stimulating and medicinal properties by the Amazonian indigenous population and communities. However, it presents serious phytopathological problems, such as anthracnose disease caused by Colletotrichum spp. The objective of this study was to verify if $C$. siamense, a mycovirus-carrying endophytic fungus, could protect guarana seedlings, by reducing or by eliminating characteristic disease symptoms. Other physiological changes in the plant caused by the presence of this endophyte were also evaluated. The cuttings of the Cereçaporanga cultivar were dipped in a biological control suspension and planted in a specific substrate. After four months in the greenhouse, the seedlings were sprayed with a suspension of phytopathogen conidia, and a portion of these seedlings received the fungicide indicated for the crop to be compared with the control seedlings. After 28 days, the number of lesions, morphophysiological and macro characteristics, and leaf micronutrients were evaluated. 
The seedlings treated with $C$. siamense showed a lower percentage of lesions and an increased aerial part and root system compared to the other treatments. There were no significant differences between treatments regarding the percentage of macronutrients and micronutrients.

Keywords: mycovirus; amazon; Paullinia cupana.

\section{INTRODUCTION}

Guarana (Paullinia cupana Kunt. var. sorbilis (Mart.) Ducke), also called guarana-da-Amazônia, guaranaina, guaranauva, uarana, or narana, is a species native to the Amazon region and is known for its stimulating and medicinal properties. The species has been used for centuries by the indigenous communities in the Amazon and more recently by the local population [1]. Guarana plants are commercially cultivated only in Brazil, where annual production reaches 2,660 tons of seeds [2], of which $70 \%$ are used by soft drink industries to produce non-alcoholic carbonated beverages. Drugstores and alternative natural product stores sell the rest, mainly in the form of roasted powder seeds [3,4].

Together, the states of Amazonas and Bahia represent $95 \%$ of the planted area of guarana in Brazil; however, in the last ten years, the mean yield in Bahia has been higher than that in Amazonas. Several factors contribute to the lower productivity in the Amazon region, such as low technical qualification of producers, inadequate cultural treatment, mother plants not undergoing genetic improvement processes, and fungal diseases such as over-sprouting and anthracnose [1,4]. Even with the development of pest- and disease-resistant cultivars for the Amazon region, productivity remains low.

The anthracnose disease of guarana plants is caused by Colletotrichum spp., which cause the young leaves to crest and fall. In young growing leaves and in immature leaves, the symptoms include necrotic lesions with a circular to elliptical shape. When abundant, these lesions cause leaf deformations and rolling, especially when they reach the ribs. Mature or old leaves are not infected. Successive attacks of this fungus induce the descending death of the branches and subsequently of the entire plant [5].

Biological control is an alternative method to the use of agrochemicals that can be efficient with lower maintenance cost and less aggression to the ecosystem, which is gaining attention in the world [6]. An alternative that has been the subject of numerous studies in recent years is the use of fungi infected with a mycovirus to control phytopathogens. A study investigating mycovirus infection in the filamentous fungus Cryphonectria parasitica provided a strong basis for future research in fungal hypovirulence or debilitation in other species of fungi $[7,8]$. The interaction between the mycovirus Cryphonectria hypovirus 1 (CHV1) with its fungal host $C$. parasitica is well studied and has been a model for several studies with other pathogenic fungi $[9,10,11]$. The presence of the virus in the host fungus can lead to several physiological changes, including decreased virulence in phytopathogenic fungi, thereby leading to the phenomenon of hypovirulence. Hypovirulence associated with mycoviruses in plant pathogenic fungi can be transmitted intraspecifically by anastomosis of hyphae in compatible isolates [12].

In 2015, from the isolation of endophytic fungi from guarana leaves in Maués (Amazonas-Brazil), the presence of mycoviruses in a species of Colletotrichum was detected using transmission electron microscopy [13]. In preliminary studies (unpublished data) the reduction of symptoms was verified in guarana seedlings inoculated with the endophyte carrying the mycovirus.

Thus, the objective of this study was to evaluate if the endophytic mycovirus-carrying $C$. siamense fungus could protect guarana seedlings of the BRS-Cereçaporanga clone, by reducing or by eliminating characteristic disease symptoms. Additionally, it evaluated whether this fungus caused physiological changes in the plant regarding its rooting potential and macronutrient and micronutrient absorption.

\section{MATERIALS AND METHODS}

\section{Microorganisms}

Endophytic fungus $C$. siamense containing a mycovirus was isolated from healthy guarana leaves at Santa Helena Farm in Maués, Amazonas ( $3^{\circ} 25^{\prime} 18.1^{\prime \prime} \mathrm{S}, 57^{\circ} 40^{\prime} 40.8^{\prime \prime} \mathrm{W}$ ), and its potential to inhibit phytopathogen growth was analyzed in vitro [13]. The Colletotrichum fructicola pathogen was isolated from guarana leaves exhibiting necrotic lesions and was included in the crop collection of the Laboratory of Phytopathology of the National Institute of Amazon Research (INPA). The pathogenicity of C. fructicola was demonstrated through the Koch's Postulate [14]. 


\section{Molecular Characterization}

\section{Extraction of DNA Genomic}

The fungi were cultivated in potato dextrose agar (PDA) medium for five days under BOD at $28^{\circ} \mathrm{C}$ and light/dark cycles (12/12 h). The mycelium was collected and underwent total nucleic acid extraction using the methodology described by Doyle \& Doyle (1990), with modifications [15].

\section{DNA Amplification by PCR}

The polymerase chain reaction (PCR) was performed to amplify the genes $\beta$-tubulin (tub), glyceraldehyde-3-phosphate dehydrogenase (gapdh), and the internal transcribed spacer (ITS) (Table 1). The amplification reaction consisted of initial denaturation at $95^{\circ} \mathrm{C}$ for $3 \mathrm{~min}$, followed by 35 cycles of denaturation at $95^{\circ} \mathrm{C}$ for $15 \mathrm{~s}$, annealing at $58^{\circ} \mathrm{C}$ for $20 \mathrm{~s}$, extension at $72^{\circ} \mathrm{C}$ for $30 \mathrm{~s}$ and a final extension step at $72^{\circ} \mathrm{C}$ for $10 \mathrm{~min}$. The amplification products underwent $1 \%$ agarose gel electrophoresis stained with ethidium bromide for $20 \mathrm{~min}$ at $80 \mathrm{~V}$. The purification was performed using a $20 \%$ polyethylene glycol (PEG) solution [16].

Table 1. Primers used in the amplification reaction

\begin{tabular}{lclc}
\hline Gene & Primer & \multicolumn{1}{c}{ Primer sequence (5'-3') } & References \\
\hline $\boldsymbol{\beta}$-Tubulin & T1 & AAC ATG CGT GAG ATT GTA AGT & [17] \\
Gt2b & ACC CTC AGT GTA GTG ACC CTT GGC & \\
phosphate & GDF & GCC GTC AAC GAC CCC TTC ATT GA & [17] \\
Internal transcribed spacer & GDR & GGG TGG AGT CGT ACT TGA GCA TGT & \\
& ITS1 & TCC GTA GGT GAA CCT GCG & [18] \\
\hline
\end{tabular}

\section{Sequencing}

After purification, the samples were prepared for sequencing using the respective Big Dye kit (Applied Biosystems) forward and reverse primers, according to the manufacturer's instructions. The sequences obtained were included and compared with those deposited in the National Center for Biotechnology Information (NCBI) nucleotide database using Basic Local Alignment Search Tool nucleotide (BLASTn). Alignment was performed with sequences showing similarity $\geq 97 \%$.

\section{Multilocus Sequence Analysis (MLSA)}

The sequences were treated and aligned using the software Geneious Prime v. 2020.2.2. Once the sequences showed high similarities in Genbank with other type strains belongs to $C$. gloeosporioides complex, a phylogenetic analyze was carried out based on sequences of type strains of these complex. A strain of $C$. boninense was used as outgroup. The sequences were then rescued and aligned with MAFFT v.7.450 [19]. After alignment, a multigene assembly of sequences was performed. For phylogenetic analysis based on the maximum likelihood and Bayesian inference, MrModelTest v. 2.3 [20] was used to choose the best evolutionary model. The phylogenetic tree was constructed using MrBayes v. 2.2.4 [21], taking into consideration the parameters generated by MrModelTest, with Markov chain Monte Carlo (MCMC), which lasted until the average standard deviation of the split frequencies was below 0.01 (1.000.000 generations). The Bayesian probability was demonstrated on the nodes between each individual. The tree was edited with FigTree v. 1.4.2 [22].

\section{Conidium Production for Testing}

The endophyte $C$. siamense was cultivated in test tubes for seven days in synthetic nutrient agar (SNA) medium under light/dark cycles $\left(12 / 12 \mathrm{~h}\right.$ ) at $30^{\circ} \mathrm{C}$. In each tube, $10 \mathrm{~mL}$ of distilled water sterilized with $1 \%$ Tween 80 were added, and then friction was generated on the surface of the medium with a soft-bristled brush to release conidia. The conidia were quantified using a Neubauer chamber, and the suspension was adjusted to a density of $5.0 \times 10^{3}$ conidia $\mathrm{mL}^{-1}$. The phytopathogen $C$. fructicola was cultivated in PDA under the same conditions, and the density of $1.0 \times 10^{6}$ conidia $\mathrm{mL}^{-1}$ was obtained following the standard used for phytopathogenic Colletotrichum species [23,24]. 


\section{In vivo testing}

\section{Cutting Preparation and Biological Control Agent Inoculation}

Fungus inoculation was conducted when cuttings of recently collected guarana branches of the BRSCereçaporanga cultivar donated by Embrapa Western Amazônia (Manaus-Amazonas) were planted. The cuttings were cut in a beveled shape and immersed in a $C$. siamense conidia suspension for $30 \mathrm{~min}$. They were planted in black bags $(23 \mathrm{~cm} \times 18 \mathrm{~cm} \times 0.15 \mathrm{~cm})$ in a substrate containing soil and sand $(4: 1)$ and left for about 120 days in a greenhouse located at the Production Project of the School of Agricultural Sciences (FCA) of the Federal University of Amazonas (UFAM). The plants were fertilized every 30 days, as indicated for the culture [4]. The cuttings were kept under intermittent nebulization from September 2018 to January 2019. The experimental design was entirely randomized with three repetitions and 12 cuttings per repetition.

\section{Cutting Preparation for Chemical Control}

The cuttings for chemical control and the control cuttings were immersed in sterile distilled water for 30 min. They were planted in bags and left in a greenhouse for about 120 days. The experimental design of this trial was the same as the previous one. The seedlings intended for chemical control were sprayed with Impact $125 \circledR$ (Flutriafol) fungicide solution, prepared according to the manufacturer's instructions, and supplemented with $2.5 \%(\mathrm{v} / \mathrm{v})$ of Agral adhesive spreader. The application was conducted using a $20-\mathrm{L}$ electric knapsack sprayer between 7:00 a.m. and 9:00 a.m. The effectiveness of the fungicide coating on the leaf surface was evaluated using an indicator paper that changed color from yellow to blue when it received drops of the product. Three fungicide applications were performed at a 15-day interval.

\section{Phytopathogen Application}

Two days after fungicide application on the group of cuttings that received the chemical treatment, the seedlings of all treatments (seedlings with the biological control agent, seedlings for chemical control, and control seedlings) were sprayed with a phytopathogen suspension. The suspension of $C$. fructicola conidia was adjusted to a density of $1.0 \times 10^{6} \mathrm{~mL}^{-1}$. After phytopathogen inoculation, the seedlings were incubated for $48 \mathrm{~h}$ in a humid chamber for conidium germination and colonization. The severity was evaluated daily in the cultivars for 28 days and measured using the diagrammatic scale of anthracnose in guarana plants [25].

\section{Morphological Analysis of Seedlings}

The influence of the treatments on the morphological characteristics of the plants was evaluated at the end of the trials by analyzing root systems and aerial parts. Fresh aerial mass (FAM), fresh root mass (FRM), aerial height $(\mathrm{APH})$, and root length $(\mathrm{RL})$ were evaluated on the same day using a measuring tape $(\mathrm{mm})$. The root system and the aerial part of each plant were placed in paper bags for subsequent drying in an oven with forced ventilation at $60^{\circ} \mathrm{C}$ until constant weight. Dry aerial mass (DAM) and dry root mass (DRM) were determined using an analytical scale.

\section{Macronutrient and Micronutrient Analysis}

After 28 days of the experiment, 20 leaves were randomly removed from each treatment (chemical control, biological control, and control) to determine macronutrients (nitrogen, phosphorus, potassium, calcium, magnesium, and sulfur) and micronutrients (boron, copper, iron, manganese, and zinc) [26]. The analysis of plant tissue was performed in the Laboratory of Soil Analysis of the Federal University of Lavras, following the standard protocol for foliar macronutrient and micronutrient analysis [27].

\section{Statistical Analysis}

The data were subjected to analysis of variance and the Tukey's mean test at $1 \%$ and $5 \%$ significance using the SISVAR 5.7 software [28]. Lesion data and morphological evaluation were transformed $(x+1)$ and subjected to analysis of variance. 


\section{RESULTS}

\section{Molecular Characterization}

The fungus used as a biological control was confirmed to be $C$. siamense and the phytopathogenic lineage was confirmed to be $C$. fructicola through gene amplification with ITS, tub, and gapdh primers and analysis of the nucleotide database [29]. These sequences were compared with those present in the NCBI bank (Table 2) and the phylogenetic tree was created (Figure 1).

Table 2. Microorganisms identified by sequences of TUB, GAPDH, and ITS genes after comparison with those deposited in the National Center for Biotechnology Information (NCBI).

\begin{tabular}{cccc}
\hline & \multicolumn{3}{c}{ GenBank accession number } \\
\hline Identification & TUB & GAPDH & ITS \\
Colletotrichum siamense & $\mathrm{MH} 622636.1$ & $\mathrm{MH} 681376.1$ & $\mathrm{KP} 703364.1$ \\
Colletotrichum fructicola & $\mathrm{MH} 622670.1$ & $\mathrm{MH} 681411.1$ & $\mathrm{MK} 041517.1$ \\
\hline
\end{tabular}

\section{Anthracnose Control Test}

The leaves of the seedlings presenting characteristic anthracnose lesions (Figure 2) were classified by the percentage of lesioned area according to the diagrammatic scale for anthracnose in guarana plants [25]. The data were analyzed, and the means have been shown in Table 3.

Table 3. Means obtained after evaluation of the percentage of lesions.

\begin{tabular}{cc}
\hline TREATMENTS & LESIONS \\
\hline Colletotrichum siamense & $5 \% \mathrm{~b}$ \\
Control & $7 \% \mathrm{ab}$ \\
Chemical & $8 \% \mathrm{a}$ \\
C.V. $(\%)$ & 2.02 \\
p-value & 0.0019 \\
\hline
\end{tabular}

Means followed by the same letter do not differ by the Tukey's test at $5 \%$ significance $(p<0.05)$. 


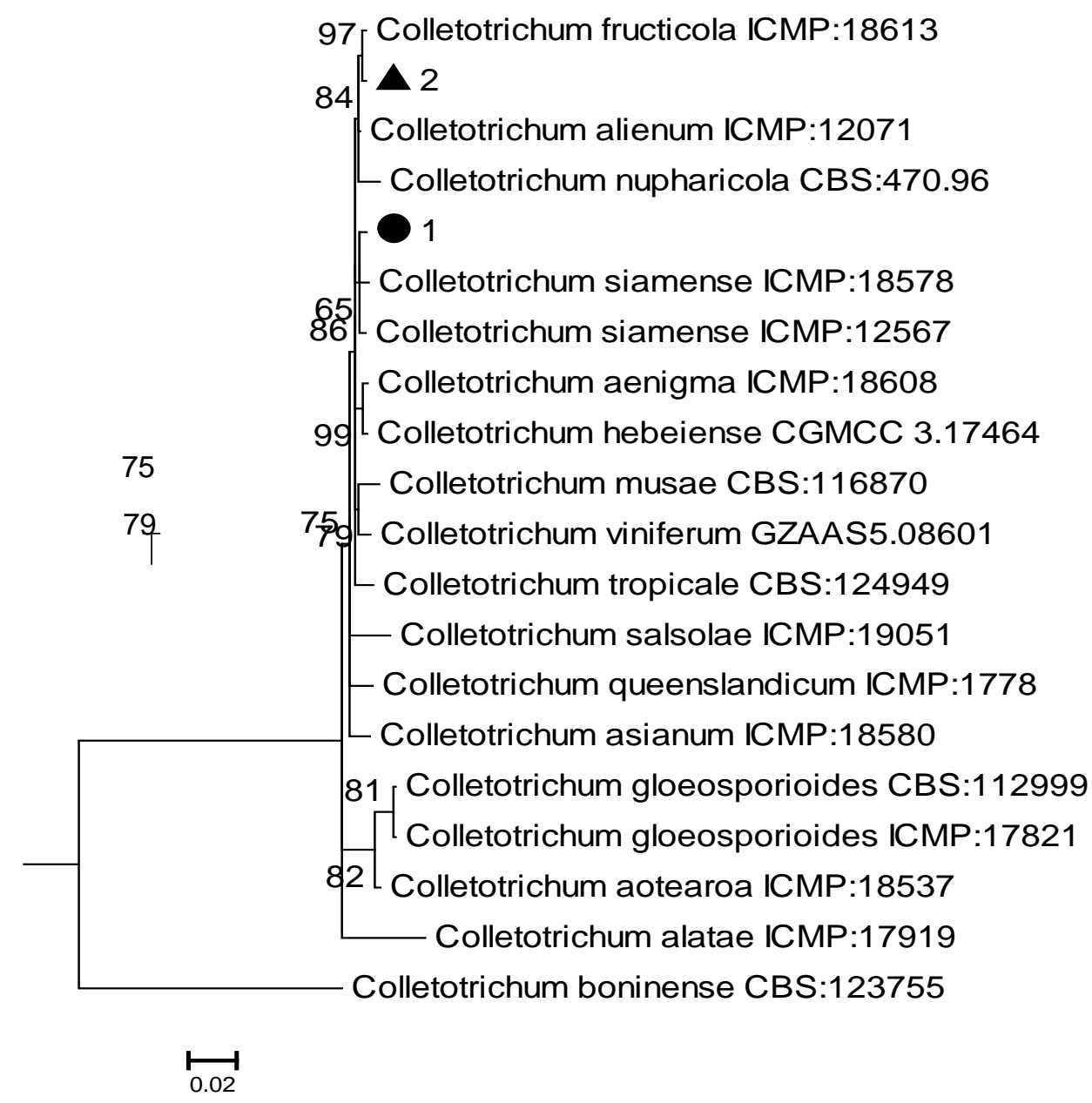

Figure 1. Cladogram results of the Bayesian analysis. The MLSA analyze was made with the alignment of three genes combined (ITS, GAPDH and TUB). The Bayesian probability was demonstrated on the nodes between each individual. The sequences of Colletotrichum boninense (CBS 123755) were used as outgroup. Fungi: $1-C$. siamense, $2-C$. fructicola.
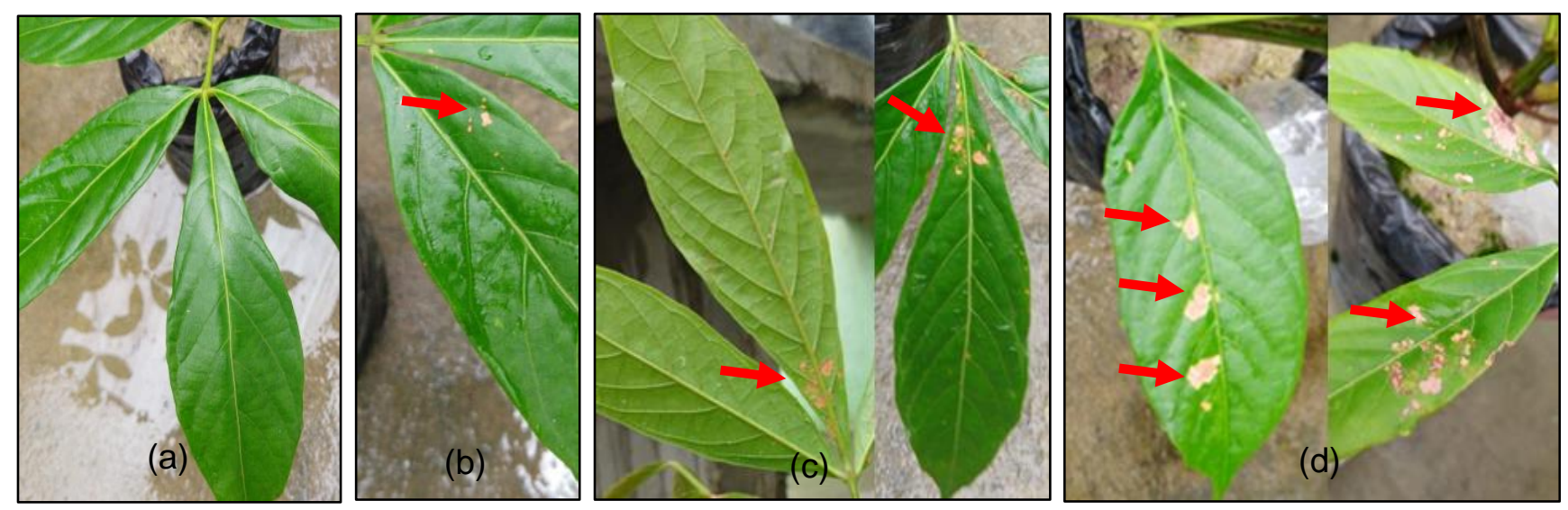

Figure 2. Guarana leaves: (a) Uninoculated; (b) Seedling treated with biological control agent C. siamense; (c) Seedling treated only with the pathogen; (d) Seedling treated with a fungicide. The arrows showed the foliar symptoms caused by Colletotrichum fructicola

\section{Leaf Macronutrient and Micronutrient Analysis}

The results of the macronutrient and micronutrient foliar analysis are shown in Table 4. Some lesions not specifically related to phytopathogenic attack were observed in seedlings of all treatments. 
Table 4. Results of the foliar analysis after the greenhouse experiment.

\begin{tabular}{|c|c|c|c|c|c|c|c|}
\hline \multicolumn{8}{|c|}{ Macronutrients $\left(\mathrm{g} \mathrm{Kg}^{-1}\right)$} \\
\hline & & $\mathbf{N}$ & $\mathbf{P}$ & $\mathbf{K}$ & $\mathrm{Ca}$ & $\mathbf{M g}^{\star \star}$ & $\mathbf{S}^{*}$ \\
\hline Control & & $27.8 \mathrm{c}$ & $2.8 \mathrm{a}$ & $21.4 \mathrm{c}$ & $2.6 \mathrm{~b}$ & $1.5 \mathrm{a}$ & $1.6 \mathrm{a}$ \\
\hline Chemical & & $30.2 b$ & $2.8 \mathrm{a}$ & $23.3 \mathrm{~b}$ & $2.7 \mathrm{a}$ & $1.5 \mathrm{a}$ & $1.6 \mathrm{a}$ \\
\hline Colletotrichum siamense & & $31.0 \mathrm{a}$ & $2.2 \mathrm{~b}$ & $24.0 \mathrm{a}$ & $2.3 \mathrm{c}$ & $1.4 \mathrm{a}$ & $1.3 \mathrm{~b}$ \\
\hline C.V $(\%)$ & & 0.53 & 5.44 & 0.62 & 3.95 & 6.82 & 6.67 \\
\hline $\mathrm{p}$-value & & 0.000 & 0.0029 & 0.0000 & 0.0066 & 0.4219 & 0.0156 \\
\hline \multicolumn{8}{|c|}{ Micronutrients $\left(\mathrm{mg} \mathrm{Kg}^{-1}\right)$} \\
\hline & B & & $\mathrm{Cu}$ & $\mathrm{Fe}$ & \multicolumn{2}{|c|}{ Mn } & $\mathrm{Zn}$ \\
\hline Control & $17.6 \mathrm{~b}$ & & $11.1 \mathrm{a}$ & $59.6 \mathrm{a}$ & \multicolumn{2}{|c|}{$117.9 \mathrm{a}$} & $36.3 \mathrm{~b}$ \\
\hline Chemical & $16.8 \mathrm{c}$ & & $11.3 \mathrm{a}$ & $67.3 \mathrm{a}$ & \multicolumn{2}{|c|}{$113.0 \mathrm{~b}$} & $37.9 \mathrm{a}$ \\
\hline $\begin{array}{l}\text { Colletotrichum } \\
\text { siamense }\end{array}$ & $19.0 \mathrm{a}$ & & $9.40 \mathrm{~b}$ & $52.3 b$ & \multicolumn{2}{|c|}{$95.1 \mathrm{c}$} & $32.5 \mathrm{c}$ \\
\hline C.V $(\%)$ & 0.56 & & 1.63 & 0.29 & \multicolumn{2}{|c|}{0.13} & 0.49 \\
\hline$p$-value & 0.0000 & & 0.0000 & 0.0000 & \multicolumn{2}{|c|}{0.0000} & 0.0000 \\
\hline
\end{tabular}

Means followed by the same letter do not differ by the Tukey's test at $5 \%$ significance $(p<0.05)$.

*Significant effect at $1 \%(p<0.01) ;{ }^{* *}$ Significant effect at $5 \%(p<0.05)$

\section{Morphological Evaluation of Seedlings}

There was a significant difference among the three treatments for the FAM, DAM, and DRM parameters (Table 5). The APH parameter presented equal means between the chemical control and control seedlings, whereas the plants receiving $C$. siamense showed increased development. As for $R L$, there was no significant difference between treatments.

Table 5. Results of the morphological parameters obtained after 150 days of the experiment.

\begin{tabular}{|c|c|c|c|c|c|c|}
\hline & $\begin{array}{c}\text { Fresh aerial } \\
\text { mass } \\
\text { (FAM) } \mathrm{g}\end{array}$ & $\begin{array}{c}\text { Fresh root } \\
\text { mass (FRM) } \\
\text { g } \\
\end{array}$ & $\begin{array}{l}\text { Dry aerial } \\
\text { mass } \\
\text { (DAM) } \mathrm{g}\end{array}$ & $\begin{array}{c}\text { Dry root } \\
\text { mass } \\
\text { (DRM) } g\end{array}$ & $\begin{array}{c}\text { Aerial part height } \\
\text { (APH) } \\
\text { cm }\end{array}$ & $\begin{array}{l}\text { Root length } \\
\text { (RL) } \\
\text { cm }^{\star *} \\
\end{array}$ \\
\hline Control & $28.28 \mathrm{c}$ & $5.72 \mathrm{c}$ & $8.94 \mathrm{c}$ & $1.69 \mathrm{~b}$ & $53.83 \mathrm{~b}$ & $25.27 \mathrm{a}$ \\
\hline Chemical & $33.36 \mathrm{~b}$ & $8.11 b$ & $11.64 \mathrm{~b}$ & $2.69 a$ & $55.33 \mathrm{~b}$ & $26.06 \mathrm{a}$ \\
\hline $\begin{array}{l}\text { Colletotrichum } \\
\text { siamense }\end{array}$ & $39.42 \mathrm{a}$ & $9.53 \mathrm{a}$ & $12.97 \mathrm{a}$ & $2.69 \mathrm{a}$ & $59.94 \mathrm{a}$ & $27.61 \mathrm{a}$ \\
\hline C.V. (\%) & 13.86 & 20.44 & 14.20 & 15.38 & 6.15 & 8.11 \\
\hline $\mathrm{p}$-value & 0.0000 & 0.0000 & 0.0000 & 0.0001 & 0.0007 & 0.0885 \\
\hline
\end{tabular}

Means followed by the same letter do not differ by the Tukey's test at $5 \%$ significance $(p<0.05)$.

*Significant effect at $1 \%(p<0.01) ;{ }^{* *}$ Significant effect at $5 \%(p<0.05)$. 


\section{DISCUSSION}

Colletotrichum species can be found in nature as pathogens, endophytes, and sometimes as saprophytes [30]. Both $C$. siamense and $C$. fructicola have already been isolated as phytopathogens $[31,32]$ and as endophytes in different hosts [33,34]. The behavior of Colletotrichum species is known to be highly regulated by specific gene families and biochemical interactions that occur through specific enzymes and secondary metabolites produced at the host-pathogen interface. This interaction generally defines how the fungus will present itself and how it can establish necrotrophic, hemi-biotrophic, latent or quiescent, and endophytic relationships [30]. In this study, $C$. siamense behaved as an endophyte and $C$. fructicola behaved as a phytopathogen. Thus, both were documented for the first time in guarana plants.

The proposal to use endophytic fungi as biological control agents has been considered for different crops. Several studies used potential mycovirus-carrying control agents associated with the natural ability of endophytes to protect the plant due to their ability to produce antimicrobial substances [35]. The use of $C$. siamense resulted in fewer lesions in the evaluated seedlings (Table 3 ) when compared to the control and the plants receiving the chemical treatment. Three hypotheses can be considered to explain this outcome. The first is related to the capacity of transmitting the mycovirus to the phytopathogenic lineage, as suggested by some authors [36]. A study on the effects of Colletotrichum fructicola chrysovirus 1 (CfCV1) in C. fructicola showed that its presence decreased the growth rate and virulence in pears. Mycovirus-carrying Colletotrichum species, such as $C$. higginsianum, C. truncatum, and $C$. camelliae, also showed changed phytopathogenic behavior due to the presence of the mycovirus [37-39]. The second hypothesis is that host tissue colonization by the endophytic lineage decreases the establishing capacity of the phytopathogen. The advantages of using endophytes and hypovirulent lineages as biological control agents include the capacity of these microorganisms to occupy the same niche as occupied by the phytopathogen [40]. The biological control agent prevents host infection by occupying the same niche, by colonizing entry points, and by using the same nutrients that would be used by the phytopathogen [41]. The third hypothesis is based on the stimulus of the plant to produce protective substances, a phenomenon denominated as induced systemic resistance. Several additional substances, including indoleacetic acid (IAA) produced by C. siamense [42], produce specific pathogenesis-related proteins in plant cells that can degrade the cell wall of fungi and bacteria.

The benefits of phytopathogen inhibition were evaluated only on the BRS-Cereçaporanga cultivar. However, it is important to emphasize that these beneficial responses may vary on the basis of host genetics $[43,44]$. This suggests that different results can be expected when using the same control agent in other guarana cultivars. The different improvement processes applied to this guarana crop resulted in discrete changes in the morphological characteristics of the plant, such as cuticle thickness, stomatal density, presence of trichomes, and so on. [43]. These characteristics can also influence the process of phytopathogen colonization by facilitating (or not) its entry into the host. The improved cultivars demonstrated good field tolerance to the phytopathogen. This is the case for the BRS-Maués cultivar, currently selected as the most promising cultivar due to its productivity and tolerance to anthracnose [44]. However, there are no studies explaining which gene or set of genes is involved in this tolerance process.

The seedlings treated with the fungicide and the controls showed a slightly higher percentage of symptoms (Table 3). This preliminarily showed that the fungicide indicated to control the disease in this crop did not minimize phytopathogenic effects on the plant. Although this active ingredient has already been indicated to control anthracnose in guarana plants, it is not a common practice among farmers due to the high costs of using the product.

As for the macronutrient and micronutrient analysis of the plant material, the seedlings treated with $C$. siamense had higher $\mathrm{N}$ and $\mathrm{K}$ levels in foliar tissues (Table 4). Associated with $\mathrm{N}$, aside from constituting approximately $2 \%$ to $5 \%$ of the dry mass of the plant, $\mathrm{K}$ increases vegetative growth $[45,46]$. The results obtained can be directly related to the fact that the seedlings treated with $C$. siamense exhibit higher mean FAM, DAM, and RL compared to the control and chemical-control seedlings (Table 5). Studies on tomato seedlings (Solanum lycopersicum L.) showed that endophytic microorganisms increased N, P, K, Ca, Mg, $\mathrm{Cu}$, and $\mathrm{Zn}$ levels in the aerial part and $\mathrm{N}, \mathrm{P}, \mathrm{Mg}$, and $\mathrm{Mn}$ in the roots, thus improving nutritional efficiency [47].

Throughout the experiment, there were foliar changes not directly related to the phytopathogen attack. Symptoms such as rolling, chlorosis, and leaf spots are mostly related to nutrient absence or excess. As for guarana seedlings, the few recommendations regarding fertilization are related to the addition of $25 \mathrm{~mL}$ of $\mathrm{KCl}$ and urea solution directly in the substrate every 30 days. However, it is known that seedlings in the development phase may require a larger amount of nutrients, specifically micronutrients, which improve 
processes such as the release of new leaves. Table 4 shows the macronutrient and micronutrient levels found in the leaves. Although there are discrete differences between nutrient contents, there is no significant difference among treatments.

The growth-promoting effect of several microorganisms has been recognized for a long time and explored in different crops [48-50]. However, studies with Amazonian species and especially with guarana are rare in the literature. This study showed that the seedlings treated with $C$. siamense presented greater vegetative growth when compared to the control. More specifically, they showed increased dry matter and height of the aerial part (Table 5). A study with Arabidopsis thaliana showed that treatment with $C$. tofieldiae increased the dry mass of the plant [51]. Moreover, the presence of $C$. tofieldiae increased phosphate absorption from the soil, directly increasing the vegetative growth of the plant. Thus, it is of interest to use microorganisms considered to be bio-stimulants in the production phase of seedlings since this is one of the most important stages of the agricultural production system, as the final plant performance in the field depends on it [52]. Several studies confirm the stimulant effect of some fungi on plants, with Trichoderma being the most widely used genus [50,53,54].

In guarana plants, this increased dry mass in the seedlings treated with the biological control agent may be a consequence of IAA production by the fungus. IAA is a dominant type of auxin found in plants, which is involved in cell growth and elongation responses, cell differentiation, and root initiation. This hormone is also produced by plant-associated microorganisms, including ectomycorrhizal, endophytes, and phytopathogens. IAA production by $C$. siamense was evaluated in vitro, thereby corroborating the findings in the literature on the production of this hormone by Colletotrichum species [42,55].

\section{CONCLUSION}

The results showed that the inoculation of $C$. siamense in guarana seedlings reduced the percentage of lesions caused by the phytopathogen. Additionally, the presence of the fungus improved the vegetative growth of the plant and increased the aerial part of the seedling. There were no significant differences among treatments regarding micronutrient levels in foliar tissues. New studies are needed to understand the protection mechanisms of $C$. siamense in guarana plants.

Acknowledgments: This study was financed in part by the Coordenação de Aperfeiçoamento de Pessoal de Nível Superior - Brasil (CAPES) - Finance Code 001. We thank FAPEAM for their financial support and Embrapa Western Amazon for the technical support and consultancy.

Conflict of Interest: The authors declare no conflict of interest. Funders had no influence on study design, data collection, analysis or interpretation, manuscript writing, or the decision to publish the results.

\section{REFERENCES}

1. Schimpl FC, Silva JF, Gonçalves JFC, Mazzafera P. Guarana: Revisiting a highly caffeinated plant from the Amazon. J. Ethnopharmacol. 2013 Oct 28;150(1):14-31.

2. Instituto Brasileiro de Geografia e Estatística (IBGE): SIDRA - Banco de Tabelas Estatísticas [internet] [updated 2017 jun 30 cited 2019 Jan 10]. Available from: https://sidra.ibge.gov.br/

3. Ângelo PCS, Nunes-Silva CG, Brígido MM, Azevedo JSN, Assunção EN, Sousa ARB et al. Brazilian Amazon Consortium for Genomic Research (REALGENE). Guarana (Paullinia cupana var. sorbilis), an anciently consumed stimulant from the Amazon rain forest: the seeded-fruit transcriptome. Plant Cell Rep. 2008 Jan;27(1):117-24.

4. Pereira JCR. Sistemas de Produção 2: Cultura do guaranazeiro no Amazonas. 4th ed. Manaus: Embrapa Amazônia Ocidental; 2005.

5. Tavares AM, Atroch AL, Nascimento Filho FJ, Pereira JCR, Araújo JCA, Moraes LAC. Cultura do Guaranazeiro no Amazonas. 4th ed. Manaus: Embrapa Amazônia Ocidental; 2005.

6. Azevedo JL, Maccheroni Junior W, Pereira JO, Araújo WL. Endophytic microorganisms: a review on insect control and recent advances on tropical plants. Electron J Biotechn. 2000 Apr 15;3(1):40-65.

7. Ghabrial SA, Suzuki N. Viruses of plant pathogenic fungi. Annu Rev Phytopathol. 2009 47:353-84.

8. Eusebio-Cope A, Sun L, Tanaka T, Chiba S, Kasahara S, Suzuki N. The chestnut blight fungus for studies on virus/host and virus/virus interactions: From a natural to a model host. Virology 2015 Mar;477:164-75.

9. Chu YM, Jeon J, Yea S, Kim Y, Yun S, Lee Y et al. Double-stranded RNA mycovirus from Fusarium graminearum. Appl Environ Microbiol. 2002 May;68(5):2529-34.

10. Zhou T, Boland GJ. Hypovirulence and double-stranded RNA in Sclerotinia homeocarpa. Phytopathology 1997 Feb;87(2):147-53. 
11. Wu M, Zhang L, Li G, Jiang D, Ghabrial SA. Genome characterization of a debilitation-associated mitovirus infecting the phytopathogenic fungus Botrytis cinerea. Virology 2010 Oct 10;406(1):117-26.

12. Anagnostakis SL, Day PR. Hypovirulence conversion in Endothia parasitica. Phytopathology 1979 69:1226-29.

13. Bezerra TE. Potencial biotecnológico dos fungos endofíticos do guaraná (Paullinia cupana var. sorbilis) no controle biológico da antracnose [thesis]. Manaus: Universidade Federal do Amazonas; 2015.

14. Bezerra CS. Caracterização enzimática de Colletotrichum spp. isolados de Paullinia cupana Kunth. var. sorbilis (Mart.) [dissertation]. Manaus: Instituto Nacional de Pesquisas da Amazônia; 2017.

15. Doyle JJ, Doyle JL. Isolation of plant DNA from fresh tissue. Focus 1990 12:13-15.

16. Teles YV. Seleção e isolamento de bactérias resistentes a cromo hexavalente endêmicas do igarapé do quarenta [thesis]. Manaus: Universidade Federal do Amazonas; 2017.

17. Silva BNS, Ferreira AFTAF, Mota AJ, Bentes JLS. Occurrence of noni anthracnose caused by Colletotrichum siamense in Amazonas, Brazil. Agrarian Academic J. 2019 Mai/Jun;2(3):7-9.

18. White J, Bruns T, Lee S. Amplification and direct sequencing of fungal ribosomal RNA genes for phylogenetics. In: Innis MA, Gelfand DH, Sninsky JJ, White TJ, editors. PCR protocols: a guide to methods and applications. New York: Academic Press Inc; 1990. p.315-22.

19. Katoh K, Standley DM. MAFFT Multiple Sequence Alignment Software Version 7: Improvements in Performance and Usability. Mol. Biol. Evol. 2013 30(4):772-80.

20. Nylander JAA. MrModeltest v2. Program distributed by the author. Evolutionary Biology Centre, Uppsala University 2004.

21. Ronquist F, Teslenko M, Van Der Mark P, Ayres DL, Darling A, Höhna S, Huelsenbeck JP. MrBayes 3.2: efficient Bayesian phylogenetic inference and model choice across a large model space. Syst. Biol. 2012 61(3):539-42.

22. Rambaut A. 2009. FigTree v1. 3.1: Tree figure drawing tool. Website: <http://tree.bio.ed.ac.uk/software/figtree>

23. Lins SRO, Abreu MS, Alves E. Estudos histopatológicos de Colletotrichum spp. em plântulas de cafeeiro. Fitopatol Bras. 2007 Nov/Dez;32(6):488-95.

24. Souza LCR. Resistência de genótipos de pimenta-de-cheiro (Capsicum chinense Jacq.) à antracnose (Colletotrichum brevisporum) [dissertation]. Manaus: Instituto Nacional de Pesquisas da Amazônia; 2018.

25. Pereira JCR, Araújo JCA. Escala diagramática para quantificar a antracnose do guaranazeiro. Comunicado Técnico 70. Manaus: Embrapa Amazônia Ocidental; 2009.

26. Batista BD. Promoção de crescimento em milho (Zea mays L.) por rizobactérias associadas a cultura do guaranazeiro (Paullinia cupana var. sorbilis) [dissertation]. Piracicaba: Escola Superior de Agricultura Luiz de Queiroz; 2012.

27. Malavolta E, Vitti GC, Oliveira SA. Avaliação do estado nutricional das plantas: princípios e aplicações. Piracicaba: Potafos; 1997.

28. Ferreira DF. Sisvar: a computer statistical analysis system. Ciência e Agrotecnologia 2011 Nov 30;35(6):1039-42.

29. Prihastuti H, Cai L, Chen H, McKenzie EHC, Hyde KD. Characterization of Colletotrichum species associated with coffee berries in northern Thailand. Fungal Divers. 2009 Dec 9;39:89-109.

30. Silva DD, Crous PW, Ades PK, Hyde KD, Taylor PWJ. Life styles of Colletotrichum species and implications for plant biosecurity. Fungal Biol Rev. 2017 May;31:155-68.

31. Dwarka DJ, Sharma G, Rajasab AH. Colletotrichum siamense causes anthracnose on the fruits of Pongamia pinnata in India. Mycosphere 2016 Aug 21;7(4):492-98.

32. Mo J, Zhao G, Li Q, Solange GS, Tang L, Guo, T et al. Identification and characterization of Colletotrichum species associated with mango anthracnose in Guangxi, China. Plant Dis. $2018 \mathrm{Jul} ; 102: 1283-89$.

33. Zakaria L, Aziz WNW. Molecular identification of endophytic fungi from banana leaves (Musa spp.). Trop Life Sci Res. 2018 Jul 6;29(2):201-11.

34. Ma X, Nontachaiyapoom S, Jayawardena RS, Hyde KD, Gentekaki E, Zhou S. Endophytic Colletotrichum species from Dendrobium spp. in China and Northern Thailand. MycoKeys 2018 Dec 4;43:23-57.

35. Rosseto P, Costa AT, Polonio JC, Silva AA da, Pamphile JA, Azevedo JL. Investigation of mycoviruses in endophytic and phytopathogenic strains of Colletotrichum from different hosts. Genetics and Molecular Research 2016 15(1):1-8.

36. Zhai L, Zhang M, Hong N, Xiao F, Fu M, Xiang $\mathrm{J}$ et al. Identification and characterization of a novel heptasegmented dsRNA virus from the phytopathogenic fungus Colletotrichum fructicola. Front Microbiol 2018 Apr 19;9(754):1-13.

37. Campo S, Gilbert KB, Carrington JC. Small RNA-Based Antiviral Defense in the phytopathogenic fungus Colletotrichum higginsianum. PLOS Pathog. 2016 Jun 2;12(6):1-36. 
38. Marzano SL, Nelson BD, Ajayi-Oyetunde O, Bradley CA, Hughes TJ, Hartman GL et al. Identification of diverse mycoviruses through metatranscriptomics characterization of the viromes of five major fungal plant pathogens. $J$ Virol. 2016 Aug;90(15):6846-63.

39. Jia H, Dong K, Zhou L, Wang G, Hong N, Jiang D. A dsRNA virus with filamentous viral particles. Nat Commun. 2017 Aug 1;8(168):1-12.

40. O'Brien PA. Biological control of plant diseases. Australas Plant Pathol. 2017 Mar 23;46(4):293-304.

41. Sneh B. Use of non-pathogenic or hypovirulent fungal strains to protect plants against closely related fungal pathogens. Biotechnol Adv. 1998 Jan;16(1):1-32.

42. Munasinghe MVK, Kumar NS, Jayasinghe L, Fujimoto Y. Indole-3-Acetic Acid production by Colletotrichum siamense, an endophytic fungus from Piper nigrum leaves. Journal of Biologically Active Products from Nature 2017 Dec 28;79(6):475-9.

43. Oliveira ERN. Características morfofisiológicas e bioquímicas de clones de guaraná Paullinia cupana Kunt. var. sorbilis (Mart.) Ducke cultivados sob plantio comercial na Amazônia [thesis]. Manaus: Instituto Nacional de Pesquisas da Amazônia; 2014.

44. Pinto CEDL, Atroch AL, Fajardo JDV, Nascimento Filho FJ. Seleção de clones de guaranazeiro para adaptabilidade e estabilidade no estado do Amazonas. Amazonian Journal of Agricultural and Enviromental Sciences 2018 61:1-7.

45. Silveira RLVA, Malavolta E. Nutrição e adubação potássica em Eucalyptus. Piracicaba: Potafos; 2009.

46. Santos KG. Efeito da adubação foliar e condicionadores de solo no enraizamento, crescimento e rustificação de mudas clonais de Pinus sp. [dissertation]. Piracicaba: Escola Superior de Agricultura Luiz de Queiroz; 2015.

47. Barretti PB, Souza RM, Pozza AAA, Pozza EA, Carvalho JG, Souza JT. Aumento da eficiência nutricional de tomateiros inoculados com bactérias endofíticas promotoras de crescimento. Rev. Bras. Cienc. Solo. 2008 July/Aug;32(4):1541-48.

48. Harman GE. Myth and dogmas of biocontrol changes in perceptions derived from research on Trichoderma harzianum T-22. Plant Dis. 2000 Feb 23;84(4):377-93.

49. Resende ML, Oliveira JA, Guimarães RM, Pinho RGV, VIEIRA AR. Inoculação de sementes de milho utilizando o Trichoderma harzianum como promotor de crescimento. Cienc Agrotec. 2004 Aug;28(4):793-98.

50. Singh V, Singh PN, Yadav RL, Awasthi SK, Joshi BB, Singh RK et al. Increasing the efficacy of Trichoderma harzianum for nutrient uptake and control of red rot in sugarcane. J Hortic For. 2010 Apr;2(4):66-71.

51. Hiruma K, Gerlach N, Sacrista S, Nakano RT, Hacquard S, Kracher B et al. Root endophyte Colletotrichum tofieldiae confers plant fitness benefits that are phosphate status dependent. Cell 2016 Apr 7;165:464-74.

52. Hartmann HT, Kester DE, Davies FT, Geneve R. Plant propagation: Principles and practices. 8th ed. New Jersey: Prentice Hall; 2010.

53. Yadav J, Verma JP, Tiwari KN. Plant growth promoting activities of fungi and their effect on chickpea plant growth. Asian J Biol Sci. 2011 Feb;4(3):291-99.

54. Azevedo GB, Novaes QS, Azevedo GTOS, Silva HF, Sobrinho GGR, Novaes AB. Efeito de Trichoderma spp. no crescimento de mudas clonais de Eucalyptus camaldulensis. Sci For. 2017 Jun;45(114):343-52.

55. Numponsak T, Kumla J, Suwannarach N, Matsui K, Lumyong S. Biosynthetic pathway and optimal conditions for the production of indole-3-acetic acid by an endophytic fungus, Colletotrichum fructicola CMU-A109. Plos One 2018 Oct 18;13(10):1-17.

2021 by the authors. Submitted for possible open access publication under the terms and conditions of the Creative Commons Attribution (CC BY NC) license (https://creativecommons.org/licenses/by-nc/4.0/). 